\title{
Investigating the Role of L2 Language Proficiency in Word Association Behavior of L2 Learners: A Case of Iranian EFL Learners
}

\author{
Bahareh Khazaeenezhad \\ Department of English, Sheikhbahaee University, Iran \\ Ahmad Alibabaee \\ Department of English, Sheikhbahaee University, Iran
}

\begin{abstract}
In the last few decades word association research has provided precise insight into the development and organization of the mental lexicon; however, there is still sufficient ground for more exploration to gain a better understanding of how L2 learners' mental lexicon might be organized and how word association behavior may vary according to $\mathrm{L} 2$ proficiency level. This paper was intended to investigate the development of mental lexicon through a psycholinguistic experiment and more specifically, to explore the possible role $\mathbf{L 2}$ language proficiency may have in word association behaviors of Iranian EFL learners. To this end, a standardized English placement test (OPT) and a word association test were administered to 120 undergraduate EFL learners. The elicited responses were classified based on Peppard's (2007) model and then analyzed in terms of the frequency of each type of word association. The results indicated that upper intermediate students' responses were significantly more frequent than beginners' responses in the categories of "Synonymy" and "Hypernymy and Hyponymy" which are paradigmatic relations and the beginners' responses were significantly more frequent in the category of "Grammatical collocation" which is a syntagmatic relation. These findings, which support McCarthy (1990) and Meara (1982), are not in line with Wolter'(2001) belief about the re-evaluation of the syntagmatic-paradigmatic shift in the case of nonnative speakers. The study implies important implications for vocabulary teaching through assisting learners in building stronger semantic links between words.
\end{abstract}

Index Terms-mental lexicon, language proficiency, word association behavior, syntagmatic relation, paradigmatic relation

\section{INTRODUCTION}

The mental lexicon is "a person's mental store of words, their meaning and associations" (Richards \& Schmidt, 2002: p.327). Scholars admit that little is actually known about the mental lexicon (Aitchison, 2003; Channell, 1988; McCarthy, 1990) and all attempts to define and describe it rely on more metaphors that produce incomplete models. Brown (2006) offers a more modern metaphor, comparing it to the Internet and World Wide Web. He believes that the information in the mental lexicon, like a library or computer, is always being updated; new words are added, new connections to existing words are made and unused words may be forgotten.

McCarthy (1990) gives the following examples: "The mental lexicon is like a dictionary, a thesaurus, an encyclopedia, a library, a computer and a net" (p. 34). He further notes that the total model for the place of any word in the lexicon will have to be three dimensional; with phonological nets crossing orthographic ones and criss-crossing semantic and encyclopaedic [personal knowledge] nets (McCarthy, 1990).

Aitchison (2003) lists four main methods for researching the mental lexicon: 1) word searches (tip-of-the-tongue or TOT states) and slips of the tongue, 2) linguistics and linguistic corpora, 3) speech disorders and brain scans and 4) psycholinguistic experiments. In respect to the last of these four methods, a word association test is one measurement in psycholinguistic experiments which will be described in more detail below.

As Peppard (2007) states, the word association test (WAT) was "initially used as a psychological tool to study the subconscious mind, and more recently used by psycholinguists to explore the mental lexicon" (P. 4). In addition, according to Read (2004), a word association task is defined as one where speakers of a language are given a set of stimulus words one by one and they are instructed to give the first word that comes to their mind. Wolter (2001) identified three categories of word associations: paradigmatic, syntagmatic, and phonological or 'clang' responses. As Wolter (2001) stated, Paradigmatic responses have the same grammatical function as the prompt word and can be of four types: coordinates superordinates, subordinates, and synonyms. Syntagmatic responses have a collocational or sequential relationship with the prompt word, and are not from the same word class. Phonological or 'clang' associations are semantically unrelated but similar-sounding words. Read (1993) added a fourth category: analytic responses, which could be a definition of characteristics, as if explained in a dictionary. 
Early studies into the responses of NS children on WATs (Ervin, 1961; Palmero, 1971; Emerson \& Gekoski, 1976) found that as children aged, they produced more paradigmatic responses, and less syntagmatic and clang associations. This belief was most commonly referred to as the syntagmatic- paradigmatic (S-P) shift, and it effectively placed higher value on paradigmatic associations, holding them up as evidence of increasing proficiency. When these findings were imported to SLA, it led some researchers (e.g. Politzer, 1978) to believe that as learners' proficiency levels increased they typically provided more paradigmatic responses, whereas weaker learners tended to produce more clang or syntagmatic associations. The extension of the S-P shift to non native speakers (NNSs) was quite logical as both NNSs and NS children are in the process of learning the language (Wharton, 2010).

Although the S-P shift failed to take account of NSs who preferred giving syntagmatic responses on WATs (Nilson \& Henriksen, 2006), there was wide support for the hypothesis, and so it lasted, unchallenged, for decades (Wolter, 2001). Wolter (2001) feels the S-P shift would be better described as a "shift from semantically meaningless responses to semantically meaningful responses". Recent studies have also questioned whether a division between L1 and L2 lexicons is actually so prominent, based on the discovery that NSs are not so homogeneous after all (Nilson \& Henriksen, 2006; Fitzpatrick, 2007). In addition, the use of lesser-known prompt words revealed that NS and NNS associations were similar in the proportions of paradigmatic, syntagmatic, and clang responses produced (Wolter, 2001; Fitzpatrick, 2006; Zareva, 2007). It appears that various factors, like the 'depth of word knowledge' (Wolter, 2001) and 'word familiarity' (Zareva, 2007) greatly influence both NS and NNS associations (Wharton, 2010). Wolter (2006) contends that the most important difference between NSs and NNSs lies in the syntagmatic connections (e.g. collocations) rather than paradigmatic, as the former requires significant lexical restructuring. In addition, Wolter's (2002) study revealed that word associations in a foreign language are not clearly linked to proficiency.

Read (1993) carried out a study with university students of English and tested their knowledge of "academic" words. Read's test consisted of a target word followed by eight other words, four of which are semantically related to the target word, and four of which are not. Read's test aimed to assess receptive word knowledge and knowledge about the meaning of a word, the words with which it is associated, and the collocations in which it occurs. Read (1993, p.359) distinguished three types associations on the basis of "preliminary drafting of items": (a) paradigmatic ("The two words are synonyms or at least similar in meaning, perhaps with one being more general than the other"); (b) syntagmatic ("The two words are collocates that often occur together in a sentence"); (c) ("The associate represents one aspect, or component, of the meaning of the stimulus word and is likely to form part of its dictionary definition'). One of the most striking results of word association studies was summarized by Read (1993, p.358) as follows: One of the basic findings is that native speakers have remarkably stable patterns of word association, which can be taken to reflect the sophisticated lexical and semantic networks that they have developed through their acquisition of the language. On the other hand, second language learners produce associations that are much more diverse and unstable; often their responses are based on purely phonological, rather than semantic, links with the stimulus words.

Another issue to consider is the relationship between word-association and level of language proficiency. Research in this area has produced conflicting results with some studies pointing to the segregation of the two and some pointing to the undeniable influence of the latter on the former. As Wolter (2002) states devising a word association test (WAT) as a means of assessing proficiency in a foreign language has always had something of an inherent appeal to it. Wolter (2002) suggests that there may be something of a connection between psycholinguistic knowledge and more general proficiency in a foreign language. In respect to this last point, Wolter (2002) states that the underlying argument is that we would expect learners of higher proficiency to have more highly developed semantic networks in the L2 mental lexicon. However, his study with a group of language learners and native speakers did not support his views since he could not find any evidence that word associations in a foreign language are linked to proficiency.

Although previous studies had found no substantial evidence that language proficiency is a determinant in word association, newer research claims that it may still be possible to "develop a word association test as a means of assessing proficiency in a foreign language, despite the findings of past studies" (Wolter, 2002, p. 315). For instance, Dergisi's study (2010) revealed that proficiency in English might affect word associations and competent speakers can make generalizations about the occurrence of a word and can find associated words easily. Students in advanced level use 'superordinates' and 'subordinates' more than the students in elementary level because they connect the words in their minds more easily by establishing a network of associations than the students in elementary level (Dergisi, 2010).

Considering all the above mentioned studies, it seems that there is still a need for more exploration to gain a better understanding of how L2 learners' mental lexicon might be organized and how word association behavior may vary according to L2 proficiency level. Therefore, the present study is an attempt to expand our current understanding of the possible role L2 language proficiency may have in word association behaviors of Iranian EFL learners.

\section{Methodology}

\section{A. Participants}

Participants in this study comprised 120 EFL students, both male and female, aged between 19 to 23 who were freshman $(n=60)$ and junior $(n=60)$ students of English literature and translation fields at Sheikhbahaee University in Isfahan, Iran. The freshmen were in their first semester of their higher education; therefore, the experience they had in English was limited to what they had been taught in their educational life in guidance and high school. None of the 
freshmen participated in this study had had any other kinds of exposure to English. The junior students, besides what they had already been exposed to in pre-university stages of their educational life - being similar to freshmen in this respect - had also passed the introductory courses in learning English in university and had developed the necessary skills for communicating in English.

\section{B. Instrumentation}

\section{English Proficiency Test}

In order to determine the students' level of English language proficiency and to select students at the two levels of "beginner and elementary" and "upper intermediate" in terms of English language proficiency, the OPT was used in this study. The OPT was decided to serve the discriminatory purpose for this research, since it demands the fulfillment of language preliminaries. Another reason for this was the fact that OPT could provide the best indices of placement.

\section{Word association test}

The word association test used in this study was taken from Wolter (2002). It consisted of 20 verbs as the prompts and it was also a single response test (see Appendix A). The test included prompt words from the Edinburgh Associative Thesaurus (EAT, Kiss et al., 1973; available online at http://monkey.cis.rl.ac.uk/Eat/htdocs/eat.html). The reason for the selection of this test was that Wolter (2002) evaluated critically all the present word association tests and took all the necessary measures to prevent the shortcomings of those tests from interfering with his newly devised test. For Wolter (2002) when developing a WAT, it should be kept in mind that 1) WAT would be relatively quick and easy both to administer and to score, 2) be a nice complement to other methods of assessing learner performance and 3) tend to suggest that there may be something of a connection between psycholinguistic knowledge and more general proficiency in a foreign language.

\section{Procedures}

The two tests of OPT and word association were administered to two classes of undergraduate students at Sheikhbahaee University over a 1-week period. In the first testing session, participants were asked to take OPT and in the second the word association test was administered. Participants were given $40 \mathrm{~min}$ to do OPT and $10 \mathrm{~min}$ to do the word association test.

As the aim of this study was to investigate the possible role of language proficiency in the word association behavior of EFL learners, the researcher announced that there would be the standard test of OPT (Oxford Quick Placement Test, 2001) which determines their level of English proficiency and controls the students' homogeneity in the experiment. After the administration of the test, 44 students were ranked as 'beginner and elementary", 51 as "upper intermediate" and the rest of the participants $(n=25)$ were ranked as the lower intermediate students who were excluded from the study. The reason for not including the lower intermediate participants in the main part of the study was the intention that the two groups in this study should be distinct enough if we tended to examine the possible effect of the level English language proficiency.

\section{Data analysis}

In order to categorize the elicited responses, the association types proposed by Peppard (2007) from the related literature were adopted in this study. According to Peppard (2007), the majority of word association literature focuses on the two main organizing principles of language: syntagmatic (chain) and paradigmatic (choice) relations. Sytagmatic associations are those that would be related by a phrase or syntactic structure. Paradigmatic associations on the other hand, involve the other words that could replace the target word. Previous research has shown a tendency for native speakers to respond to word association stimuli paradigmatically and for non-native speakers to respond syntagmatically (Coulthard et al., 2000: 27; Meara, 1982). In addition to the paradigmatic/ syntagmatic distinction, word associations can be based solely on their phonological or orthographic relations. These responses, labeled $\mathrm{clang}$ responses, are far less common and usually given by low-level language learners. Finally, some responses are related to one's personal knowledge about the word; these are referred to as encyclopaedic responses. Based on the association types described above, the responses elicited from the participants of this study were categorized and presented in the following section.

\section{RESULTS AND DISCUSSION}

In total, 2000 responses (972 from beginner and elementary students and 1073 from upper intermediate students) were collected for the twenty prompt words. All of the responses were first classified into paradigmatic, syntagmatic and phonological associations. The paradigmatic responses were further classified into co-ordination, hyponymy/ hypernymy and synonymy; the co-ordination responses were in turn classified into complementary, gradable, converses and mutual incompatibles. The syntagmatic associations were further classified into lexical, grammatical and restricted collocations. The frequency of encyclopedic responses was also recorded. This initial classification is shown in Table 3.1.below. 
TABLE 3.1.

THE CLASSIFICATION OF THE EFL LEARNER' RESPONSES BASED ON PEPPARD (2007) MODEL

\begin{tabular}{|c|c|c|c|c|c|c|c|c|c|c|c|c|}
\hline \multirow{3}{*}{ Level } & \multicolumn{6}{|c|}{ Paradigmatic choice } & \multirow{2}{*}{\multicolumn{3}{|c|}{$\begin{array}{l}\text { Syntagmatic chain } \\
\text { Collocation }\end{array}$}} & \multirow{3}{*}{$\begin{array}{l}\text { Phonological } \\
\text { Or } \\
\text { Orthographical } \\
\text { relations }\end{array}$} & \multirow{3}{*}{$\begin{array}{l}\text { Encyclopedic } \\
\text { knowledge }\end{array}$} & \multirow[t]{3}{*}{ Total } \\
\hline & \multicolumn{4}{|c|}{ Co-ordination } & \multirow{2}{*}{$\begin{array}{l}\text { Hyper. } \\
\text { Hypo. }\end{array}$} & \multirow{2}{*}{ Syn. } & & & & & & \\
\hline & Comp. & Grad. & Con. & Inc. & & & Lex. & Gra. & Res. & & & \\
\hline $\begin{array}{l}\text { Begin. } \\
\text { and } \\
\text { Elem. }\end{array}$ & $\mathbf{0}$ & $\mathbf{0}$ & $\mathbf{0}$ & $\mathbf{0}$ & 25 & 73 & 360 & 169 & $\mathbf{0}$ & 44 & 256 & 927 \\
\hline $\begin{array}{l}\text { Upper } \\
\text { Interm. }\end{array}$ & 9 & $\mathbf{0}$ & 3 & $\mathbf{0}$ & 99 & 136 & 417 & 37 & $\mathbf{0}$ & 36 & 336 & 1073 \\
\hline Total & 9 & 0 & 3 & 0 & 124 & 209 & 777 & 206 & 0 & 80 & 592 & 2000 \\
\hline
\end{tabular}

As Table 3.1. shows, the most frequent type of association was "lexical collocations" (777 instances; 360 beginners, 417 upper intermediates) being syntagmatic type in terms of the relations. The second most frequent association was "encyclopedic knowledge" (592 instances; 256 beginners, 336 upper intermediates) which was followed by "synonyms" (209 instances; 73 beginners, 136 upper intermediates) and then "grammatical collocations" (206 instances; 169 beginners, 37 upper intermediates). "Hypernyms and hyponyms" were the next most frequent associations (124 instances; 25 beginners, 99 upper intermediates). The sixth and seventh most frequent associations were "phonological / orthographical relations" and "complementary co-ordinations", with 80 instances (44 beginners, 36 upper intermediates) and 9 instances ( 0 beginners, 9 upper intermediates) respectively. The least frequent association was "converses" (3 instance; 0 beginners, 3 upper intermediate). The categories of "gradable antonyms", "mutual incompatibles" and "restricted collocations" had no instances in the elicited responses.

As the aim of this study was to investigate the possible role of proficiency in word association behaviors of Iranian EFL learners, the Chi-square test was used to analyze statistically the difference between the frequencies of responses in each category. The results of Chi-square test are reported in Table 3.2. to 3.9. (see Appendix B). All in all, the differences between the frequencies of the EFL learners' responses in three categories of "Synonymy", "Grammatical collocation" and "Hypernymy and Hyponymy" were statistically significant. The results showed that upper intermediate students' responses were significantly more frequent than beginners' responses in the categories of "Synonymy" and "Hypernymy and Hyponymy" which are paradigmatic relations and the beginners' responses were significantly more frequent than upper intermediate students' responses in the category of "Grammatical collocation" which is a syntagmatic relation. The above-mentioned findings do not support those of Wolter's (2001, p. 61)), which indicated a syntagmatically dominant mental lexicon in the case of non-native speakers. Wolter argued for a "syntagmatically dominated" L2 mental lexicon and called for a re-evaluation of the syntagmatic-paradigmatic shift in the case of nonnative speakers. By contrast, the results of the present study, which do not show a preference for syntagmatic responses, are in line with previous research by Dóczi (2006), showing that the paradigmatic shift occurs with native and non-native speakers as well. The rationale behind this might be that L2 learners acquire more vocabulary during the language learning process, which might lead to a more stable organization of synonymy, hypernymy and hyponymy at higher stages of proficiency but further research needs to be carried out to verify this.

Although, in this study, the differences between the frequencies of the instances in the three categories of "Synonymy", "Grammatical collocation" and "Hypernymy and Hyponymy" were statistically significant and we can generally conclude that beginners have mostly syntagmatic word association and upper intermediate students have mostly paradigmatic word association in their mind (Coulthard et al., 2000: 27; Meara, 1982), the results of this study are not much promising for the idea that language proficiency influences word association of Iranian EFL learners in the categories of lexical collocations, encyclopedic knowledge ,phonological/orthographical relations, complementary and converse, since the differences between the frequencies in these categories are not statistically significant. This implies several avenues for further research to gain a better insight into the mental lexicon of learners as related to the above mentioned categories. All in all, the conclusion we came up with is that there is a great deal of work yet to be done and we have a long way to go in order to understand the complexity of the mental lexicon.

\section{CONCLUSION}

The purpose of this study was to gain insight into the mental lexicon of L2 learners, with a focus on Iranian EFL learners. Generally, the findings of this study demonstrated that the mental lexicon of second language learners is highly organized. Specifically, in the case of Iranian EFL learners, upper intermediate students' responses were significantly more frequent in paradigmatic relations; however the beginners' responses were significantly more frequent in syntagmatic relations. Encyclopaedic knowledge is also influential for some prompt words, which by its very nature will vary from person to person.

The findings support McCarthy (1990) and Meara (1982) but were not in line with Wolter' (2001) belief about the reevaluation of the syntagmatic-paradigmatic shift in the case of nonnative speakers. The results of this study have revealed that as L2 learners acquire more vocabulary knowledge during the language learning process and become more proficient, their responses in word association tests incline to paradigmatic relations and this paradigmatically dominant 
mental lexicon in the case of non-native speakers reflects the role of proficiency in association behavior of Iranian EFL learners. While there are no absolute conclusions as to how the L2 mental lexicon is organized, the result of the present study can have important implications for vocabulary teaching through assisting learners in building stronger semantic links between words.

\section{PEDAGOGiCAL IMPLiCATIONS}

The association that learners make on word association tests, reflect the important role these association might play in the teaching and learning of new vocabulary (Schmitt, 2000). As an alternative to simply absorbing new words through exposure or experimenting with a mnemonic technique that concentrates solely on individual features of words, a better approach might be to focus on characteristics of the entire lexicon ( Meara \& Wolter, 2004). As such, it seems logical to assist L2 learners organize their mental lexicon through promoting stronger links between words, which can facilitate vocabulary learning.

Meara (2009, p. 19) promotes the idea of developing "learning methods that, as a side effect, produced learners with native-like association patterns" in an effort to mold more proficient L2 communicators. Therefore, it would be more appropriate to use some vocabulary building activities using association, such as free association, brainstorming or mind mapping of words and topics, which might be more effective for developing L2 learners' mental lexicon as compared with direct vocabulary instruction. It is recommended to teachers to make use of such meaningful communicative activities which can help learners make meaningful connections between new and formerly learned vocabulary.

\section{APPEndix A The Word Association Test}

Instructions

The following test is a word association test. You will see a list of words with three blank spaces, and you should fill in each blank with the first English word that you think of when you read the word. There are no right or wrong answers.

1. draw

2. jump

3. care

4. bring

5. move

6. keep

7. visit

8. fall

9. break

10. travel

11. cut

12. enjoy

13. kill

14. argue

15. write

16. send

17. replace

18. apply

19. make

20. show

ApPendix B The Results of ChI-SQuare Test

TABLE 3.2

CHI-SQUARE TEST RESULTS FOR THE FREQUENCY OF THE INSTANCES OF "LEXICAL COLLOCATIONS" IN BEGINNER AND UPPER INTERMEDIATE GROUPS

\begin{tabular}{|c|c|c|c|c|c|}
\hline & Value & dt & $\begin{array}{c}\text { Asymp. Sig. } \\
\text { (2-sided) }\end{array}$ & $\begin{array}{l}\text { Exact Sig. } \\
\text { (2-sided) }\end{array}$ & $\begin{array}{l}\text { Exact Sig. } \\
\text { (1-sided) }\end{array}$ \\
\hline Pearson Chi-Square & $.007^{\mathrm{b}}$ & $\overline{1}$ & .935 & \multirow{6}{*}{1.000} & \multirow{6}{*}{.502} \\
\hline Continuity Corrections & .000 & 1 & 1.000 & & \\
\hline Likelihood Ratio & .007 & 1 & .935 & & \\
\hline Fisher's Exact Test & & & & & \\
\hline $\begin{array}{l}\text { Linear-by-Linear } \\
\text { Association }\end{array}$ & .007 & 1 & .935 & & \\
\hline $\mathrm{N}$ of Valid Cases & 555 & & & & \\
\hline
\end{tabular}


TABLE 3.3.

CHI-SQUARE TEST RESULTS FOR THE FREQUENCY OF THE INSTANCES OF "ENCYCLOPEDIC KNOWLEDGE" IN BEGINNER AND UPPER INTERMEDIATE GROUPS

\begin{tabular}{|l|c|c|c|c|r|}
\hline & Value & $\mathrm{dt}$ & $\begin{array}{c}\text { Asymp. Sig. } \\
(2 \text {-sided) }\end{array}$ & $\begin{array}{c}\text { Exact Sig. } \\
(2 \text {-sided })\end{array}$ & $\begin{array}{c}\text { Exact Sig. } \\
(1 \text {-sided })\end{array}$ \\
\hline Pearson Chi-Square & $.810^{\mathrm{b}}$ & 1 & .368 & & \\
Continuity Correction & .650 & 1 & .420 & & \\
Likelihood Ratio & .814 & 1 & .367 & & \\
Fisher's Exact Test & & & & .401 & .210 \\
Linear-by-Linear & .808 & 1 & .369 & & \\
Association & 555 & & & & \\
N of Valid Cases & & & & & \\
\hline
\end{tabular}

TABLE 3.4.

CHI-SQUARE TEST RESULTS FOR THE FREQUENCY OF THE INSTANCES OF "SYNONYMY" IN BEGINNER AND UPPER INTERMEDIATE GROUPS

\begin{tabular}{|c|c|c|c|c|c|}
\hline & Value & df & $\begin{array}{c}\text { Asymp. Sig. } \\
\text { (2-sided) }\end{array}$ & $\begin{array}{l}\text { Exact Sig. } \\
\text { (2-sided) }\end{array}$ & $\begin{array}{c}\text { Exact Sig } \\
\text { (1-sided) }\end{array}$ \\
\hline Pearson Chi-Square & $4.817^{\mathrm{b}}$ & 1 & .028 & \multirow{7}{*}{.032} & \multirow{7}{*}{.019} \\
\hline Continuity Correction? & 4.168 & 1 & .041 & & \\
\hline Likelihood Ratio & 5.107 & 1 & .024 & & \\
\hline Fisher's Exact Test & & & & & \\
\hline Linear-by-Linear & 4800 & 1 & 078 & & \\
\hline Association & 4.809 & 1 & .028 & & \\
\hline $\mathrm{N}$ of Valid Cases & 555 & & & & \\
\hline
\end{tabular}

TABLE 3.5.

CHI-SQUARE TEST RESULTS FOR THE FREQUENCY OF THE INSTANCES OF "GRAMMATICAL COLLOCATION" IN BEGINNER AND UPPER INTERMEDIATE GROUPS

\begin{tabular}{|c|c|c|c|c|c|}
\hline & Value & df & $\begin{array}{l}\text { Asymp. Sig. } \\
\text { (2-sided) }\end{array}$ & $\begin{array}{l}\text { Exact Sig. } \\
\text { (2-sided) }\end{array}$ & $\begin{array}{l}\text { Exact Sig. } \\
\text { (1-sided) }\end{array}$ \\
\hline Pearson Chi-Square & $46.904^{b}$ & 1 & .000 & \multirow{6}{*}{.000} & \multirow{6}{*}{.000} \\
\hline Continuity Correction? & 44.628 & 1 & .000 & & \\
\hline Likelihood Ratio & 49.000 & 1 & .000 & & \\
\hline Fisher's Exact Test & & & & & \\
\hline $\begin{array}{l}\text { Linear-by-Linear } \\
\text { Association }\end{array}$ & 46.819 & 1 & .000 & & \\
\hline $\mathrm{N}$ of Valid Cases & 555 & & & & \\
\hline
\end{tabular}

TABLE 3.6.

CHI-SQUARE TEST RESULTS FOR THE FREQUENCY OF THE INSTANCES OF "HYPERNYMY AND HYPONYMY" IN BEGINNER AND UPPER INTERMEDIATE GROUPS

\begin{tabular}{|c|c|c|c|c|c|}
\hline & Value & df & $\begin{array}{l}\text { Asymp. Sig. } \\
\text { (2-sided) }\end{array}$ & $\begin{array}{l}\text { Exact } \mathrm{Sig} \\
(2 \text {-sided })\end{array}$ & $\begin{array}{l}\text { Exact Sig. } \\
\text { (1-sided) }\end{array}$ \\
\hline Pearson Chi-Square & $11.365^{\circ}$ & 1 & .001 & & \\
\hline Continuity Correction? & 10.175 & 1 & .001 & & \\
\hline Likelihood Ratio & 13.330 & 1 & .000 & & \\
\hline Fisher's Exact Test & & & & .000 & .000 \\
\hline $\begin{array}{l}\text { Linear-by-Linear } \\
\text { Association }\end{array}$ & 11.344 & 1 & .001 & & \\
\hline $\mathrm{N}$ of Valid Cases & 555 & & & & \\
\hline
\end{tabular}

TABLE 3.7.

CHI-SQUARE TEST RESULTS FOR THE FREQUENCY OF THE INSTANCES OF "PHONOLOGICAL/ORTHOGRAPHICAL RELATIONS" IN BEGINNER AND UPPER

\begin{tabular}{|c|c|c|c|c|c|}
\hline & Value & df & $\begin{array}{l}\text { Asymp. Sig. } \\
\text { (2-sided) }\end{array}$ & $\begin{array}{l}\text { Exact } \mathrm{Sig} . \\
(2 \text {-sided })\end{array}$ & $\begin{array}{l}\text { Exact Sig. } \\
\text { (1-sided) }\end{array}$ \\
\hline Pearson Chi-Square & $.767^{\circ}$ & 1 & .381 & & \\
\hline Continuity Correction & .433 & 1 & .511 & & \\
\hline Likelihood Ratio & .752 & 1 & .386 & & \\
\hline Fisher's Exact Test & & & & .391 & .253 \\
\hline $\begin{array}{l}\text { Linear-by-Linear } \\
\text { Association }\end{array}$ & .766 & 1 & .381 & & \\
\hline $\mathrm{N}$ of Valid Cases & 555 & & & & \\
\hline
\end{tabular}


TABLE 3.8 .

CHI-SQUARE TEST RESULTS FOR THE FREQUENCY OF THE INSTANCES OF "COMPLEMENTARY" IN BEGINNER AND UPPER INTERMEDIATE GROUPS

\begin{tabular}{|c|c|c|c|c|c|}
\hline & Value & df & $\begin{array}{c}\text { Asymp. Sig. } \\
\text { (2-sided) }\end{array}$ & $\begin{array}{l}\text { Exact Sig. } \\
\text { (2-sided) }\end{array}$ & $\begin{array}{l}\text { Exact Sig. } \\
\text { (1-sided) }\end{array}$ \\
\hline Pearson Chi-Square & $1.937^{\mathrm{b}}$ & 1 & .164 & & \\
\hline Continuity Correction? & .637 & 1 & .425 & & \\
\hline Likelihood Ratio & 2.986 & 1 & .084 & & \\
\hline Fisher's Exact Test & & & & .284 & .225 \\
\hline $\begin{array}{l}\text { Linear-by-Linear } \\
\text { Association }\end{array}$ & 1.933 & 1 & .164 & & \\
\hline $\mathrm{N}$ of Valid Cases & 555 & & & & \\
\hline
\end{tabular}

TABLE 3.9.

CHI-SQUARE TEST RESULTS FOR THE FREQUENCY OF THE INSTANCES OF "CONVERSE" IN BEGINNER AND UPPER INTERMEDIATE GROUPS

\begin{tabular}{|c|c|c|c|c|c|}
\hline & Value & df & $\begin{array}{c}\text { Asymp. Sig. } \\
\text { (2-sided) }\end{array}$ & $\begin{array}{l}\text { Exact Sig. } \\
\text { (2-sided) }\end{array}$ & $\begin{array}{l}\text { Exact Sig. } \\
\text { (1-sided) }\end{array}$ \\
\hline Pearson Chi-Square & $.643^{\mathrm{b}}$ & 1 & .423 & & \\
\hline Continuity Correction? & .000 & 1 & 1.000 & & \\
\hline Likelihood Ratio & .993 & 1 & .319 & & \\
\hline Fisher's Exact Test & & & & 1.000 & .609 \\
\hline $\begin{array}{l}\text { Linear-by-Linear } \\
\text { Association }\end{array}$ & .642 & 1 & .423 & & \\
\hline $\mathrm{N}$ of Valid Cases & 555 & & & & \\
\hline
\end{tabular}

\section{REFERENCES}

[1] Aichison, J. (2003). Words in the Mind. Oxford: Blackwell.

[2] Brown, D. (2006). Vocabulary activities to enhance your textbook. Paper presented at annual conference of the Japanese Association of Language Teaching (JALT), Shizuoka.

[3] Carter, R. (1998). Vocabulary: Applied Linguistic Perspectives. London: Routledge.

[4] Channell, J. (1988). 'Psycholinguistic considerations in the study of L2 vocabulary acquisition.' In Carter, R. A. and McCarthy, M. J. (Eds.) Vocabulary and Language Teaching. London: Longman.

[5] Coulthard, M., Knowles, M., and Moon, R. with Deignan, A. (2000) Lexis (2ndedition). Birmingham: The Centre for English Language Studies, The University of Birmingham.

[6] Dergisi, A. (2010). Playing with words: A study on word association responses. The Journal of International Social Research,10 (3),364-365.

[7] Dóczi, B. (2006). Mapping the mental lexicon of pre-intermediate learners: Word associations in a depth of word knowledge elicitation task. In M. Nikolov \& J. Horváth (Eds.), UPRT 2006: Empirical studies in English applied linguistics (pp. 117-137). Pécs: Lingua Franca Csoport

[8] Emerson, H., \& Gekoski, W. (1976). Interactive and categorical grouping strategies and the syntagmatic-paradigmatic shift. Child Development, 47(4), 1116-1121.

[9] Ervin, S. (1961). Changes with age in the verbal determinants of word-association. The American Journal of Psychology, 74(3), 361-372.

[10] Fitzpatrick, T. (2006). Habits and Rabbits: Word association and the L2 lexicon. EUROSLA Yearbook, 6, 121 - 145.

[11] Fitzpatrick, T. (2007). Word association patterns: Unpacking the assumptions. International Journal of Applied Linguistics, 17 (3), 319-331.

[12] Jackson, H. (1988). Words and Their Meaning. London: Longman.

[13] Kiss, G.R., Armstrong, C., Milroy, R., Piper, J. (1973). An associative thesaurus of English and its computer analysis. In: Aitken, A.J., Bailey, R.W., Hamilton-Smith, N. (Eds.), The Computer and Literary Studies. University Press, Edinburgh.

[14] Lambert, W.E. (1956). Developmental Aspects of Second Language Acquisition. In: Lambert, W.E. (Ed.), Language, Psychology, and Culture. Stanford University Press, Stanford, California, pp. 9-31.

[15] McCarthy, M. (1990). Vocabulary. Oxford: Oxford University Press.

[16] Meara, P. (1982) 'Word associations in a foreign language: A report on the Birkbeck Vocabulary Project.' Nottingham Linguistic Circular. 11(2): 29-37.

[17] Meara, P. (2009). Connected words: Word association and second language vocabulary acquisition. Amsterdam: john Benjamins.

[18] Meara, P., \& Wolter, B. (2004). V_Links: Beyond vocabulary depth. Angles on the English-speaking World, 4, 85-96.

[19] Nissen, H., \& Henriksen, B. (2006). Word class influence on word association test results. International Journal of Applied Linguistics, 16(3), 389-408.

[20] Palmero, D. (1971). Characteristics of word association responses obtained from children in grades one through four. Developmental Psychology, 5(1), 118-123.

[21] Peppard, J. (2007). Exploring the Relationship between Word-Association and Learners' Lexical Development. Available online at: http://www.bhamlive1.bham.ac.uk/Documents/college-artslaw/cels/essays/lexis/PeppardMod2.pdf. Retrieved on 2012/1/29. 
[22] Politzer, R.B., (1978). Paradigmatic and syntagmatic associations of first-year French students. In: Honsa, V., Hardman-deBautista, M.J. (Eds.), Papers on Linguistics and Child Language: Ruth Hirsch Weir Memorial Volume. Mouton, The Hague.

[23] Read, J. (1993). The development of a new measure of L2 vocabulary knowledge. Language Testing, 10, 355-371.

[24] Read, J. (2004). Plumbing the depths: How should the construct of vocabulary knowledge be defined? In P. Bogaards, \& B. Laufer (Eds), Vocabulary in a second language (pp. 209-227). Amsterdam: John Benjamins.

[25] Richards, C. and Schmidt, R. (2002). Dictionary of Language Teaching \& Applied Linguistics ( $3^{\text {rd }}$ edition). London: Longman.

[26] Schmitt, N. (2000). Vocabulary in Language Teaching. Cambridge: Cambridge University Press.

[27] Stevens, A. (1994). Jung: A Very Short Introduction. Oxford: Oxford University Press.

[28] Wharton, C. (2010). The reliability of retrospective interviews in word association tests. In A. Stoke (Ed.), JALT 2009 Conference Proceedings. Tokyo: JALT

[29] Wolter, B. (2001). 'A Depth of Individual Word Knowledge Model.' Studies in Second Language Acquisition, 23: 41-69.

[30] Wolter, B. (2002). Assessing proficiency through word associations: is there still hope? System, 30, 315-329.

[31] Wolter, B. (2006). Lexical network structures and L2 vocabulary acquisition: The role of L1 lexical/ conceptual knowledge. Applied Linguistics, 27 (4), 741-747.

[32] Zareva, A. (2007). Structure of the second language mental lexicon: How does it compare to native speakers' lexical organization? Second Language Research, 23 (2), 123-153.

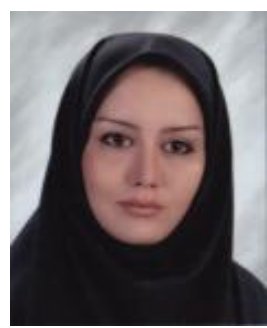

Bahareh Khazaeenezhad received her MA degree in applied linguistics and BA in English language literature from Sheikhbahaee University, Isfahan, Iran. She has published papers nationally and internationally and is currently a lecturer at the English department of Sheikhbahaee University. Her research interests include the use of literature in second language learning, language learning strategies, and the role of cognition in language acquisition.

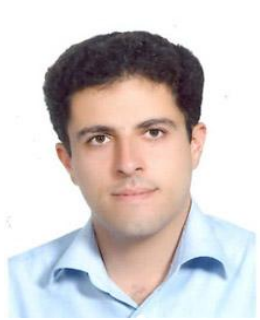

Ahmad Alibabaee was born in Mahallat, Iran in 1982. He received his B.A. Degree in English language translation from Sheikhbahaee University, Iran, in 2004. He went on to earn a Master degree in applied linguistics from the University of Isfahan, Iran, in 2006, and completed his doctorate in applied linguistics in the same university in 2010.

His carrier has included years in undergraduate and graduate teaching programs. He is currently an assistant professor in Sheikhbahaee University. His research interests include second language acquisition, research methodology, and second language assessment.

Dr. Alibabaee holds the position of peer-reviewer on the review board of the multidisciplinary academic journal GLOSSA, and the Journal of Teaching Language Skills (JTLS). 